\title{
A Case of Newly Found Lymphoepithelial Carcinoma in Retropharynx of the Patient Who Had Been in the NED State of Nasopharyngeal Carcinoma: Controversy about the Recurrence of Undiffentiated Nasopharyngeal Carcinoma
}

\author{
Yu-Young Park ${ }^{1}$, Eun-Jung Lee ${ }^{2}$, Jae-Gu Cho ${ }^{1}$, and Jeong-Soo Woo ${ }^{1}$ \\ ${ }^{1}$ Department of Otorhinolaryngology-Head and Neck Surgery, Korea University College of Medicine, Seoul, Korea \\ ${ }^{2}$ Department of Pathology, Korea University College of Medicine, Seoul, Korea
}

무병 생존 상태로 경과 관찰 중이던 비인두암 환자에서 새롭게 발견된 후인두 내 림프상피암종에 대한 증례: 미분화형 비인두암의 재발에 대한 논쟁

박유영 ${ }^{1} \cdot$ 이은정 ${ }^{2} \cdot$ 조재구 $^{1} \cdot$ 우정수 $^{1}$

고려대학교 의과대학 구로병원 이비인후-두경부외과학교실, ${ }^{1}$ 병리학교실 ${ }^{2}$

\author{
Received August 22, 2017 \\ Revised October 22, 2017 \\ Accepted November 7, 2017 \\ Address for correspondence \\ Jeong-Soo Woo, MD, PhD \\ Department of Otorhinolaryngology- \\ Head and Neck Surgery, \\ Guro Hospital, \\ Korea University \\ College of Medicine, \\ 148 Gurodong-ro, Guro-gu, \\ Seoul 08308, Korea \\ Tel $+82-2-2626-3187$ \\ Fax $+82-2-868-0475$ \\ E-mail diakonos@korea.ac.kr
}

\begin{abstract}
Lymphoepithelial carcinoma is a rare subtype of head and neck malignancy. Histologically, it is an undifferentiated carcinoma accompanied by a prominent reactive lymphoplasmacytic infiltrate. We report a case of anewly found lymphoepithelial carcinoma in the retropharynx of a patient who had been diagnosed and treated as nasopharyngeal carcinoma with multiple metastasis; the case could not be ruled out as a recurrence of nasopharyngeal carcinoma according to recent World Health Organization pathology guideline.
\end{abstract}

Korean J Otorhinolaryngol-Head Neck Surg 2019;62(3):197-200

Key Words Lymphoepithelial carcinoma - Nasopharyngeal carcinoma · Undifferentiated type.

\section{서 론}

림프상피암종(lymphoepithelial carcinoma)은 두경부에 서 발생하는 암 중 드문 악성종양으로, 타액선에서 발생하는 종양 중에서 $0.4 \%$ 를 차지하는 것으로 알려져 있다. ${ }^{1)}$ 최근 여 러 연구에서 림프상피암종은 Epstein-Barr virus(EBV)와 관

This is an Open Access article distributed under the terms of the Creative Commons Attribution Non-Commercial License (http://creativecommons.org/licenses/by-nc/4.0) which permits unrestricted non-commercial use, distribution, and reproduction in any medium, provided the original work is properly cited.
련성이 높으며, 인종지형학적으로 에스키모인, 중국인, 일본 인, 대만인에서는 $\mathrm{EBV}$ 와 관련이 있으나 서양인에서는 큰 관 련이 없다는 결과가 보고되었다. ${ }^{2-4)}$

비인두암은 비인두의 상피 세포에 생기는 비림프성의 편평 상피 세포로, World Health Organization(WHO) 분류에 따 라 다음과 같이 세 가지 유형으로 분류된다. 첫 번째 유형은 각질화된 분화암종, 두 번째 유형은 비각질화된 분화암종, 세 번째 유형은 미분화된 암종으로 나뉘며) 이 중 두 번째 및 세 번째 암종은 $\mathrm{EBV}$ 와 관련성이 있는 것으로 알려져 있다. 
과거에는 림프상피암종과 비인두암에 대해 다른 질환으로 분류하였으나, 새로운 WHO guideline에 따르면 세 번째 유 형인 미분화된 비인두암과 림프상피암종을 동의어로 간주하 는 최신 지견이 대두되고 있다. ${ }^{6)}$ 본 논문은 원발 전이된 비인 두암을 진단 받고 수술 및 항암, 방사선 치료요법을 통해 무 병 생존 상태로 경과 관찰하던 환자에서 새롭게 발생한 후인 두 내 병변에 대한 증례로, 림프상피암종과 미분화형 비인두 암의 재발에 대한 구분의 의미에 대해 고찰할 수 있기에 증 례를 보고하고자 한다.

\section{증 례}

60세 남자가 경부 전산화단층촬영상 발견된 우측 후인두 의 조영 증강되는 림프절에 대하여 조직검사를 위해 2012년 본원 이비인후과 협진 의뢰되었다. 환자는 2001년 경부 림프 절 전이를 동반하는 우측 비인두암 진단 하에 타원에서 우 측 변형 근치적 림프절제술 및 39회의 방사선 치료를 받고 온 상태였고 2002년 본원 종양내과로 내원한 뒤 시행한 검사상 에서 척추 및 폐 전이소견을 보여 척추 전이에 대한 방사선 치 료 및 $1 \mathrm{~L} 10 \mathrm{C}$ 항암치료(docetaxel, cisplatin), 폐 전이에 대한 방사선 치료를 시행하였다. 그 뒤 경과 관찰하던 중 2004년
골반 뼈 전이에 대한 완화 방사선 치료와 2L8C 항암치료(cisplatin, TS-1) 및 2007년 우측 액와부와 대동맥 림프절 전이 에 대한 3L8C 항암치료(docetaxel, cisplatin), 2008년 12월 대동맥 주위, 대동정맥, 문맥 대정맥 림프절 전이에 대한 4L8C 항암치료(cisplatin, TS-1)를 진행하였다. 환자는 경과 관찰하던 중 2012년 경부 전산화단층촬영상 우측 후인두 림 프절의 $21 \times 21 \mathrm{~mm}$ 크기의 조영 증강되는 림프절을 보였고 (Fig. 1), 이에 대해 이비인후과 협진 하에 전신 마취를 통한 조직 검사를 시행하였다. 병리 결과상 조직은 후인두 연부 조 직에서 기원한 것으로, 조직 내 $\mathrm{EBV}$ 동소 부합검사상 양성 및 cytokeratin에 염색되는 상피세포와 백혈구 공통항원 (CD45)에 염색되는 림프세포가 동시에 존재하는 림프상피 암종으로 진단되었다(Fig. 2). 치료를 위해 다학제 진료가 진 행되었고, 환자 10 년간 원발 병변인 비인두에서 무병 생존 상 태로 경과 관찰한 점을 고려하였을 때 비인두암의 재발보다 는 새롭게 발생한 림프상피암종으로 결론지었다. 환자는 과 거 수차례의 항암 및 방사선 치료를 받은 점을 고려하여 세 기 조절 방사선 치료 및 항암치료를 시행 받았고, 치료 이후 5년 동안 재발없이 경과 관찰중이다(Fig. 3).
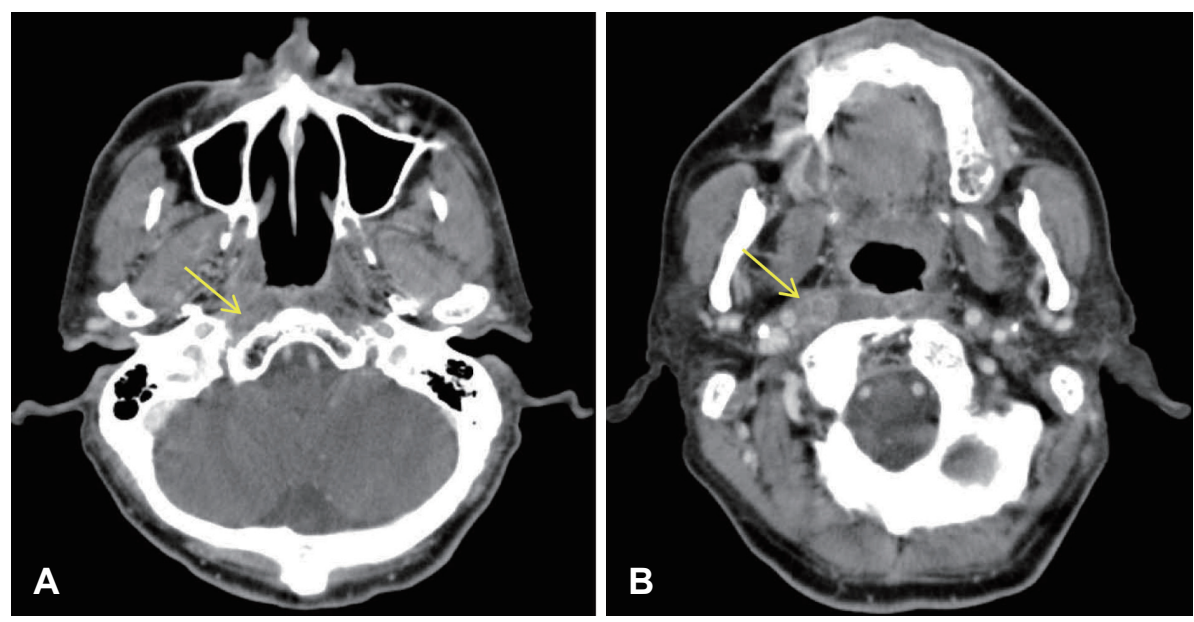

Fig. 1. CT axial views at 7 years ago when the patient was referred to ENT clinic, contrast enhanced CT axial image shows (A) intact nasopharynx, implying no recurrence of cancer (arrow) (B) but, $21 \times 21 \mathrm{~mm}$ sized heterogeneous enhancement lesion on right retropharyngeal lymph node (arrow).
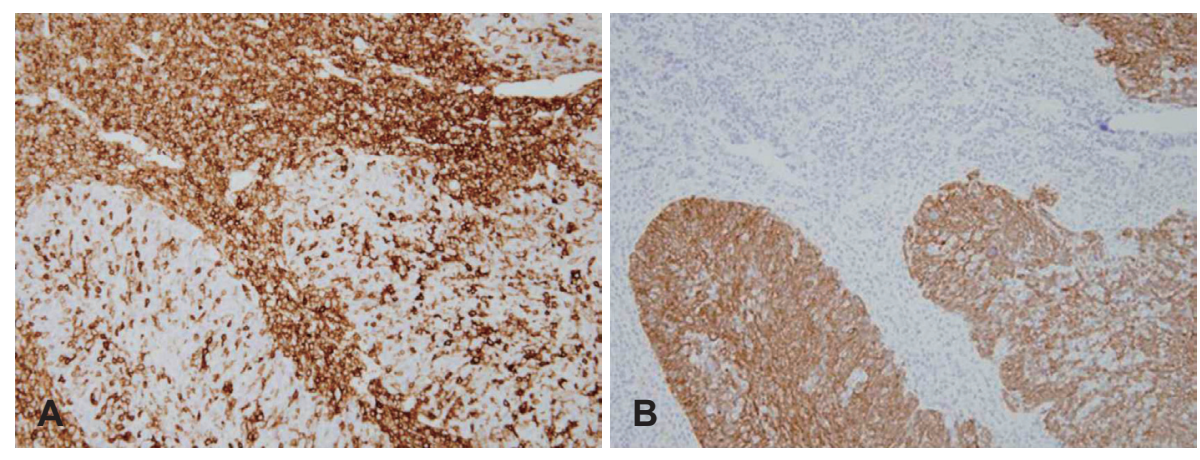

Fig. 2. Histopathologic findings of retropharyngeal lesion. At upper portion, lymphocytes were stained clearly with LCA and some lymphocytes in lower portion were also stained (LCA stain, $\times 200)(A)$. At lower portion, numerous epithelial cells in carcinoma were stained with cytokeratin (Cytokeratin stain, $\times 200$ ) which correlates with lymphoepithelial carcinoma (B). LCA: leukocyte common antigen. 


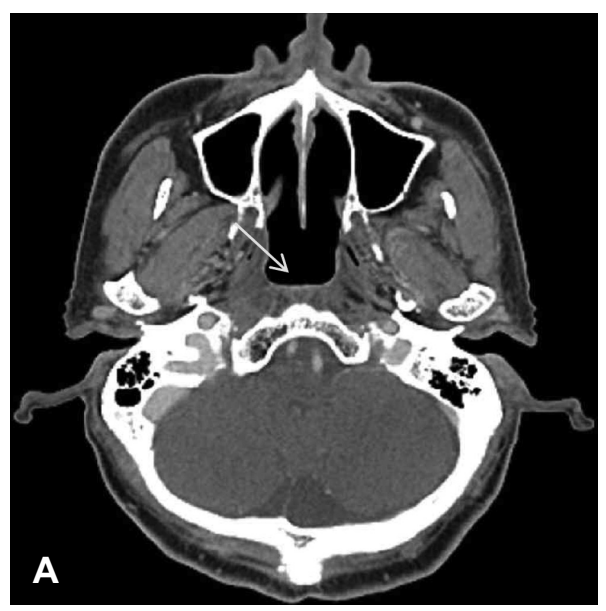

고 찰

림프상피암종은 양성의 림프상피종양에서 편평상피세포 기원의 이형성 세포가 존재하고, 주변에 림프구 침윤이 특징 적인 병리학적 소견을 보인다. Hilderman 등)에 의해 1962 년 최초로 보고되었으며, 현재까지 소수의 증례 보고가 있었 고, 타액선 종양의 $0.4 \%$ 를 차지할 정도로 매우 드문 질환이 다. ${ }^{1)}$ 국내에서 타액선에 생긴 증례는 10 예가 보고되었으며 그 중 이하선에 발생한 증례는 7건이다. ${ }^{8)}$

여러 연구에서 림프상피암종은 EBV와 관련성이 높으며, 인종지형학적으로 에스키모인, 중국인, 일본인, 대만인에서 는 $\mathrm{EBV}$ 와 관련이 있으나 서양인에서는 큰 관련이 없다는 결 과가 보고되었다. ${ }^{2-4)}$ 또한 원발 부위에 따라서 소침샘, 후두, 하인두, 신우에서 발생하는 림프상피암종은 $\mathrm{EBV}$ 와 관계없 는 것으로 보고되었으며, ${ }^{9)}$ 비인두, 타액선, 흥선 부위의 림프 상피암종은 모두 EBV와 관련이 있는 것으로 알려져 있다. 타액선 림프상피암종의 발병에서 EBV가 lymphocyte에서 나 와 타액선으로 들어가 세포증식을 일으키는 것으로 알려져 있으나 예후 및 치료에 있어 EBV의 역할에 대해서는 정확하 게 밝혀진 바가 없다.

한편, WHO 분류에 따르면 비인두암은 세가지 유형으로 분 류되며 첫 번째 유형은 각질화된 분화암종, 두 번째 유형은 비각질화된 분화암종, 세 번째 유형은 미분화된 암종으로 나 뉜다. ${ }^{5)}$ 이 중 두 번째 및 세 번째 유형은 EBV와 관련성이 있 으며, 이들 유형의 경우 병리학적으로 다수의 림프구의 침윤 을 특징으로 하여 림프상피암종과의 관련성을 가지는 것으로 알려져 있다. ${ }^{10)}$ 본 환자의 경우 2001년 비인두암 진단 당시 타 원에서 조직검사를 시행하여 초기 조직형의 확인이 불가능 하였기 때문에 후인두 병변에 대해 새롭게 발생한 림프상피 암종과 미분화된 비인두암의 전이에 대한 구분이 어려웠다. 림프상피암종의 특징인 $\mathrm{EBV}$ 동소부합검사에서 양성 소견을
보였으나, 이는 비인두암에서도 나타나는 특징이며, ${ }^{10,11)}$ 따라 서 이에 대한 임상적 판단이 필요하였다. 본 증례의 경우 원 발 병변인 비인두에 대해 10년간 무병생존상태로 지내온 점 을 고려하여 새롭게 생긴 일차성 림프상피암종으로 진단 후 세기 조절 방사선 치료를 시행하였다. 그러나 최근의 WHO guideline에 따르면, 미분화된 암종과 림프상피암종을 동의 어로 볼 정도로 가까운 유사성을 가진 범주로 간주한다.) 따 라서 본 증례의 경우도 5년 전 진단 당시 림프상피암종으로 보았으나 최신 지견을 고려하면 림프상피암종과 미분화된 비 인두암과의 구별이 의미가 없어 결국 비인두암의 재발로도 볼 수 있다는 맹점이 존재한다.

$\mathrm{Li}$ 등 $^{22}$ 의 중국 내 재발성 비인두암종의 임상적 특징에 대 한 논문에 따르면, 재발성 비인두암종 중에서 미분화된 암종 이 가장 많았으며, 이는 $92.7 \%$ 로 $0.7 \%$ 인 각질화된 분화암종 과 $7 \%$ 인 비각질화된 분화암종에 비해 압도적으로 많은 비율 을 차지하였다. 또한 전체 재발성 비인두암 환자에서 첫 진단 당시 비인두 부위에만 침범했던 188 명의 환자 중 31 명의 환 자에서 후인두 부위를 포함하는 구인두 내 재발을 동반하였 다. 본 증례도 새롭게 발견된 후인두 부위를 비인두 암종의 재발로 본다면, Jia-Xin $\mathrm{Li}$ 의 연구와 같이 확률적으로 가장 빈번한 미분화된 비인두 암종일 가능성이 크다.

림프상피암종은 조직학적으로 분화도가 낮은 악성종양으 로 분류되며, 다른 암종에 비해 방사선에 민감하여 방사선 치료에 대한 반응이 비교적 좋은 편이다.,13) 최근에는 세기 조 절 방사선 치료(intensity modulated radiation therapy, IMRT) 를 통해 림프상피암종의 국소 재발율을 줄이고, 생존율을 높 이고 있다. ${ }^{14,15)}$ 한편, 비인두암의 치료도 방사선 치료를 기본 으로 하며, 림프상피암종과 마찬가지로 방사선 치료로 인한 구강 내 합병증을 최소화하면서 높은 국소 제어율을 보이는 세기 조절 방사선 치료의 효과가 대두되고 있다. ${ }^{16)}$ 본 증례에 서 환자는 항암 및 방사선 치료의 과거력을 고려하여 세기 
조절 방사선 치료를 시행하였고, 현재 치료 후 5년 동안 재발 없이 경과관찰 중인 상태로 이를 통해 치료 및 예후적 측면 에 있어 림프상피암종과 미분화된 비인두암의 유사성을 다시 한 번 확인할 수 있다.

결론적으로 원발성 림프상피암종과 미분화된 비인두암은 최신 WHO guideline을 바탕으로 EBV와의 높은 연관성과 치료법 및 예후의 유사성을 고려하였을 때 같은 질환으로 보 는 것이 적합하며, 이를 통해 지금까지 진단된 원발성 림프상 피암종 증례에 대해서도 미분화된 비인두암의 가능성을 고 려하여 새로운 고찰이 필요할 것으로 보인다.

\section{REFERENCES}

1) El-Mofty SK. Tumors of the salivary glands, Atlas of tumor pathology, 3rd Series, Fasc 17. Modern Pathology 1997;10(4):303.

2) Hamilton-Dutoit SJ, Therkildsen MH, Neilsen NH, Jensen H, Hansen JP, Pallesen G. Undifferentiated carcinoma of the salivary gland in Greenlandic Eskimos: demonstration of Epstein-Barr virus DNA by in situ nucleic acid hybridization. Hum Pathol 1991;22(8):811-5.

3) Leung SY, Chung LP, Yuen ST, Ho CM, Wong MP, Chan SY. Lymphoepithelial carcinoma of the salivary gland: in situ detection of Epstein-Barr virus. J Clin Pathol 1995;48(11):1022-7.

4) Saw D, Lau WH, Ho JH, Chan JK, Ng CS. Malignant lymphoepithelial lesion of the salivary gland. Hum Pathol 1986;17(9):914-23.

5) Sidler D, Thum P, Winterhalder R, Huber G, Haerle SK. Undifferentiated carcinoma of nasopharyngeal type (UCNT): a Swiss single-institutional experience during 1990-2005. Swiss Med Wkly 2010;140(19-20):273-9.

6) El-Naggar AK, Chan JKC, Grandis JR, Takata T, Slootweg PJ. WHO classification of head and neck tumours, Volume 9. 4th ed. Lyon: WHO;2017. p.64-70.
7) Hilderman WC, Gordon JS, Large HL Jr, Carroll CF Jr. Malignant lymphoepithelial lesion with carcinomatous component apparently arising in parotid gland. A malignant counterpart of benign lymphoepithelial lesion? Cancer 1962;15:606-10.

8) Yim CD, Won SJ, Joo YH, Woo SH. Epstein-Barr virus positive primary lymphoepithelial carcinoma of the parotid gland with hot uptake of the nasopharynx at positron emission tomographycomputed tomography. Korean J Otorhinolaryngol-Head Neck Surg 2016;59(4):313-6.

9) Chow TL, Chow TK, Lui YH, Sze WM, Yuen NW, Kwok SP. Lymphoepithelioma-like carcinoma of oral cavity: report of three cases and literature review. Int J Oral Maxillofac Surg 2002;31(2): 212-8.

10) Brennan B. Nasopharyngeal carcinoma. Orphanet J Rare Dis 2006; 1:23.

11) Mirzamani N, Salehian P, Farhadi M, Tehran EA. Detection of EBV and HPV in nasopharyngeal carcinoma by in situ hybridization. Exp Mol Pathol 2006;81(3):231-4.

12) Li JX, Lu TX, Huang Y, Han F. Clinical characteristics of recurrent nasopharyngeal carcinoma in high-incidence area. Scientific World Journal 2012;2012:719754.

13) Allen MW, Schwartz DL, Rana V, Adapala P, Morrison WH, Hanna $\mathrm{EY}$, et al. Long-term radiotherapy outcomes for nasal cavity and septal cancers. Int J Radiat Oncol Biol Phys 2008;71(2):401-6.

14) Daly ME, Chen AM, Bucci MK, El-Sayed I, Xia P, Kaplan MJ, et al. Intensity-modulated radiation therapy for malignancies of the nasal cavity and paranasal sinuses. Int J Radiat Oncol Biol Phys 2007;67 (1):151-7.

15) Madani I, Bonte K, Vakaet L, Boterberg T, De Neve W. Intensitymodulated radiotherapy for sinonasal tumors: Ghent University Hospital update. Int J Radiat Oncol Biol Phys 2009;73(2):424-32.

16) Zhang L, Chen QY, Liu H, Tang LQ, Mai HQ. Emerging treatment options for nasopharyngeal carcinoma. Drug Des Devel Ther 2013; 7:37-52. 